\title{
Recklessness Re-examined: In Pursuit of the Conscientious Objective
}

\author{
Mitchell Davies*
}

Two decisions of the House of Lords delivered on 19 March 1981, rudely awakened the legal profession from a settled repose, alerting it to the publication of a new chapter on the definition of recklessness. This development was particularly unexpected as the debate had seemingly been closed by a series of decisions of the Court of Criminal Appeal ${ }^{1}$ which defined recklessness (in full accord with it being descriptive of a mental state) as requiring a subjective appreciation of risk by the defendant. ${ }^{2}$

The prevailing definition of recklessness had been that the accused must have foreseen the particular danger as possibly resulting from his act, but that despite this realisation he had nevertheless gone on to do the act. ${ }^{3}$ This relatively straightforward proposition was wrested away from English jurisprudence by the majority of the House of Lords in $R$. v. Caldmell. ${ }^{4}$ Barely had the future course of recklessness been plotted when the objectivist approach received further endorsement from the House in $R$. v. Lawrence. $^{5}$ At the helm in each case was Lord Diplock ${ }^{6}$ by whom a course was steered into a heavy trough of objectivity.

It may be convenient at this point to repeat the definition of recklessness which issues from Lord Diplock's judgment in $R$. v. Caldwell, with which Lords Keith and Reid concurred. His Lordship there stated:

"In my opinion a person charged with an offence under Section 1(1) Criminal Damage Act 1971 is 'reckless as to whether any such property would be destroyed or damaged' if (1) he does an act which in fact creates an obvious risk that property will be destroyed or damaged and (2) when he does the act he either has not given any thought to the possibility of there being any such

* Of The School Of Law, University of Buckingham.

1. R. v. Briggs (note) [1977] 1 W.L.R. 605; R. v. Dayl Parker [1977] I W.L.R. 600; R. v. Stephenson [1979] Q.B. 695.

2. The subjectivist approach had also been endorsed by the House of Lords in the context of the civil law in Herrington v. $B R B$ [1972] A.C. 877.

3. See, e.g., R. v. Cunningham [1957] 2 Q.B. 396.

4. [1982] A.C. 341.

5. [1982] A.C. 510.

6. Who, it should be noted, had been a member of the House of Lords in Herrington v. BRB, supra n.2. 
risk or has recognised that there was some risk involved and has nevertheless gone on to do it."7

It is to be observed that the two parts of the test equate with what for convenience may be described as the actus reus and mens rea of the adjective 'reckless'. It may be noted at this point that Lord Diplock was adamant that wherever an offence employed the term 'reckless' it necessitated a consideration of the defendant's mental state. ${ }^{8} \mathrm{He}$ also stressed that 'reckless' was an ordinary English word and it was its popular or dictionary meaning of "careless, regardless or heedless" which was to be ascribed to it. ${ }^{9}$ This was considered to be the direct result of Parliament jettisoning the awareness-based requirement of 'malice' (a central feature of the Malicious Damage Act 1861) in favour of 'reckless' under the Criminal Damage Act 1971.

It is to be observed that the objective element of the above test - the first part of the second limb - is in direct conflict with the recommendations made by both the Law Commission in $1978^{10}$ and the Criminal Law Revision Committee in 1980. ${ }^{11}$ The Law Commission has repeated its preferred definition of recklessness in the Draft Criminal Code Bill 1985 at clause $22^{12}$ where, in its determination, the objective limb from Caldwell becomes 'heedlessness' as opposed to 'recklessness'. The most recent development has been the publication, in April 1989, by the Law Commission of a Draft Criminal Code ${ }^{13}$ based upon that produced in 1985 by a team of distinguished academic lawyers. ${ }^{14}$ This new and comprehensive Criminal Code Bill is the result of a detailed scrutiny of the 1985 code undertaken by practising lawyers who have comprised eight regional 'scrutiny groups' each under the chairmanship of a circuit judge. Significantly, an entirely subjective definition of recklessness is employed thereunder. ${ }^{15}$ This most recent proposal for reform is therefore the culmination of a detailed examination of 'recklessness' by both academic and practising lawyers and marks the clear confluence of opinion that Parliament should intervene to reverse the perceived anathema created by the twin decisions of the House of Lords.

Later in the day which had witnessed the majority decision in Caldwell, a unanimous House of Lords in $R$. v. Lamrence was to endorse the earlier decision in the context of a charge of causing death by reckless driving. Lord Diplock again gave the leading judgment and re-iterated the test which he had expounded in Caldmell, though the nature of the risk which the defendant must have created

7. [1982] A.C. 341 , at p.354.

8. In deference to Lord Diplock's expressed intention 'recklessness' will be referred to, throughout this article, as a state of mind, although a contrary view is developed in the following pages.

9. [1982] A.C. 510 , at p.525.

10. Report on the Mental Element in Crime: Law Commission No. 89.

11. 14th Report, Offences Against the Person: Cmnd. 7844, Para. 11.

12. Law Commission No. 143 (1985).

13. Law Commission No. 177 (1989).

14. Which included Professors E. Griew and J. Smith.

15. Ibid., at clause 18 . 
mysteriously became "... an obvious and serious risk. .." (of causing physical injury). ${ }^{16}$

\section{Is the new test of 'recklessness' descriptive of a state of mind?}

It should be stressed at this point that despite Lord Diplock's substantial re-working of the legal definition of recklessness, he was insistent that it should be considered, nevertheless, as continuing to represent a state of mind. In Lawrence the Court of Appeal had certified as a question of general public importance whether "mens rea [is] involved in the offence of driving recklessly?" Lord Diplock answered this question unequivocally in the affirmative. ${ }^{17}$ Whilst many commentators remain unconvinced, there exists an abundance of dicta from both House of Lords' decisions leaving one in no doubt as to Lord Diplock's intentions. In Caldwell his Lordship drew a distinction between 'recklessness' and 'maliciousness' and made the observation ${ }^{18}$ that although the latter term imports actual appreciation of risk on the part of the accused: "Neither state of mind seems to me to be less blameworthy than the other..."

Furthermore, in Lawrence his Lordship compared the offences of careless and reckless driving as contained within the Road Traffic Act 1972 as amended by the Criminal Law Act 1977 . He concluded ${ }^{19}$ that the former does not necessarily involve any moral turptitude; the heavy inference therefore is that the latter does.

Upon closer scrutiny it may be considered that there is some force in the view that the new test of recklessness fails to represent a test of mens rea, which conventionally has demanded an examination of the accused's mental faculties, with the objective of ascertaining the existence or no of a directing mind, conscious of the prohibited act which the body was engaged in. Returning to his Lordship's judgment in Caldmell, the test was clearly presented as one which maintained a requirement of mens rea, but a closer scrutiny reveals that it has more than a veneer of a test, which at its broadest, may simply amount to an assessment of the defendant's conduct, regardless of his mental state. ${ }^{20}$ The relevant passage commences with Lord Diplock asserting ${ }^{21}$ that the concept of mens rea requires a consideration of what the accused himself actually appreciated, and accordingly: "... it cannot be the mental state of some non-existent, hypothetical person."

This was, however, only by way of prelude to a mandate expressed in the following paragraph to disregard entirely the mental processes of the accused, by measuring his conduct against the universal 'norm' of the reasonable man. His Lordship thus continued: "Nevertheless to decide whether someone has been

16. [1982] A.C. 510, at p.526.

17. Ibid., at p.527.

18. [1982] A.C. 341 , at p.352.

19. [1982] A.C. 510 , at pp.524-525.

20. Indeed, Lord Diplock appears to confirm this in Lawrence when he states (ibid., at p.525) that recklessness ". . . refers not only to the state of mind of the doer of the act when he decides to do it but also qualifies the manner in which the act itself is performed." 
reckless ... does call for some consideration of how the mind of the ordinary prudent individual would have reacted in a similar situation."

The role of the obdurate reasonable man was promoted later in the day in Lawrence where his Lordship observed:

“One does not speak of a person acting 'recklessly' even though he has given no thought at all to the consequences of his act, unless the act is one that presents a real risk of harmful consequences which anyone acting with reasonable prudence would recognise and give heed to." 22

It has already been observed that Lord Diplock undoubtedly intended that 'recklessness' should continue to be perceived as a term going to mens rea, but as the above dicta illustrate it is enough if the risk is evident to a reasonable man and this accordingly obviates the need to explore the mind of the accused at all. Despite his Lordship's assertions, with great respect, and in the language of Lord Templeman uttered in another place, ${ }^{23}$ one may well term a five pronged digging instrument a spade but this fails to render it any less obvious what in fact it is. One needs to look no further than Lord Diplock's assimilation of reckless conduct with that which is "careless, regardless or heedless" exact nature of the judicial tool manufactured in Caldwell. It is significant that Lord Hailsham, in Lamrence, whilst expressing total agreement with Lord Diplock, reached the opposite conclusion on this point. He stated that 'recklessness' has consistently been construed as: ". . . a state of mind stopping short of deliberate intention, and going beyond mere inadvertence, or in its modern though not its etymological and original sense, mere carelessness." 25

Furthermore, referring to the defendant's claim that he was driving his motor-cycle at between $30-40$ m.p.h. Lord Hailsham stated that since the area was 'built up' this conduct was "possibly careless, but most improbably reckless". ${ }^{26}$

It is indeed regrettable that this fundamental conflict, which lays bare a significant divergence in the two Law Lords' perceptions of how 'recklessness' should be defined, apparently eluded the Lord Chancellor as he then was.

Certain of the post-Caldwell/Lawrence (hereafter referred to as 'Caldwell) authorities are ripe to be prayed in aid to challenge the view of certain commentators who maintain that 'recklessness' does necessarily continue to represent a state of mind. Chief amongst these is Elliott v. $C^{27}$ which, it is contended, is, both in terms of its result and the manifest disenchantment of the

21. [1982] A.C. 341 , at p.354.

22. [1982] A.C. 510 , at p.525.

23. Street v. Mountford [1985] 2 All E.R. 289, at p.294.

24. [1982] A.C. 510 , at p.525.

25. Ibid., at p.520.

26. Ibid., at p. 519 .

27. [1983] 1 W.L.R. 939. 
Divisional Court with the Caldwell test, compelling evidence that 'recklessness' no longer necessarily imports a requirement of mens rea, as previously understood.

Elliott concerned a fourteen year old girl who attended a remedial school and was undoubtedly of limited intellect. Whilst seeking sanctuary one night in a garden shed she had inadvertently burnt it down, after having used the contents of a bottle of white spirit to start a fire in order to keep warm. She was charged under S.1 (1) Criminal Damage Act 1971 with intentionally or recklessly ${ }^{28}$ damaging the property of another. The justices had construed Caldwell as requiring the risk in question to be obvious to the individual concerned. Accordingly, account was taken of her limited intelligence and fatigue, which manifested itself in her claim, credible in the circumstances, that she was unaware that white spirit was highly flammable. On appeal to the High Court the decision was reversed, with it being stressed that Caldwell required the question of whether a risk was 'obvious' to be answered by an application of the reasonable man test, it being irrelevant that the risk was far from obvious to the defendant herself. The defendant's conviction was reached, however, with great reluctance and not without Robert Goff LJ alluding to what he plainly regarded as being the perverse consequences of an application of Lord Diplock's principles to the facts. ${ }^{29}$ Drawing upon Goff LJ's clear reluctance to convict the accused, it is arguable that if death had resulted, with the charge being one of reckless conduct manslaughter, the objections against conviction, based on her lack of mens rea, would have become compelling. ${ }^{30}$

With respect, the author echoes the sentiments of Goff LJ in the above case. Whilst the decision was wholly unjust, the directions of Lord Diplock reproduced above clearly contemplate the conviction of such an individual. There had been the creation of an obvious and serious risk of harm and evidence of this state of affairs was quite enough to convict the accused without the need to investigate her mental processes. In his Lordship's words, she was simply an individual who had "not given any thought to the possibility of there being any risk". Into the same category as Elliott falls $R$. v. Bell ${ }^{31}$ which serves as a further example that requirements of mens rea may be dispensed with under Caldmell with the consequential perpetuation of inequity.

In Bell, the accused, having wreaked havoc through the streets of Bridlington by driving his car indiscriminately into the vehicles of other road users, was charged

28. And "without lawful excuse": $S .1(1)$.

29. Cf., Mitchell (1988) 52 (3) Jo. of Crim. Law 300. Though if the author's views there are correct in stating that the reasonable man should be endowed with the permanent characteristics of the accused, as in the defence of provocation (D.P.P. v. Camplin [1978] A.C. 705), it may be questioned why the Appeal Committee of the House of Lords in both Elliott v. C. and Stephen Malcolm v. R. (infra p32 in text) roundly refused leave to appeal.

30. Though the judge will, upon conviction for manslaughter, have complete sentencing discretion. This may be of little comfort to the defendant, however, as there is little uniformity between the judges as to what constitutes a blameworthy state of mind; taking Elliott, Lord Diplock would seemingly have viewed her as blameworthy; Lord Hailsham may not have; and Goff and Ackner LJJ would not have. 31. [1984] 3 All E.R. 842. 
with driving recklessly contrary to the Road Traffic Act 1972. At the time of these incidents the defendant claimed that he believed the other vehicles contained evil spirits and that he was motivated into committing the acts of destruction by the voice of God. The defendant's further contention was that, consumed by this outside force, he gave no thought to the risks associated with his actions. At first instance he was convicted of the offence. Robert Goff LJ again delivered the judgment, this time of the Court of Appeal, concluding that the conviction must stand: even if the jury believed the defendant's contention, he (as in Elliott) had created an obvious and serious risk of harm in circumstances where no thought had been given to the possibility of any risk, and was accordingly within the Caldwell definition of recklessness.

The reservations expressed in Elliott regarding the Diplock direction on recklessness were cited with approval by Ackner $L J$ whilst giving the judgment of the Court of Appeal in Stephen Malcolm v. $R .^{32}$ His Lordship, whilst aligning himself totally with the dicta of Goff $\mathrm{LJ}$, nevertheless rejected the contention of counsel before him that the reasonable man should be endowed with certain characteristics of the accused such as his age and intelligence. In so doing, however, Ackner LJ was clearly much fortified in his conclusion, albeit one which was strictly superfluous to the result, that a boy of the appellant's age would inevitably have recognised the risks inherent in the appellant's conduct. If the appellant before Ackner LJ had, for example, been of retarded intellectual ability causing him to be unable to appreciate the risks associated with his conduct, his Lordship would, like Goff LJ in Elliott, only have affirmed the conviction, being constrained by authority to do so. It seems that the objection shared by Ackner and Robert Goff LJJ was the spectre of convicting the defendant with so serious an offence, in the absence of there being any true evidence of mens rea.

As observed by counsel for the appellant in Stephen Malcolm v. $R$. a prohibition (which it is here submitted is implicit in the Caldwell test) ${ }^{33}$ from considering the particular characteristics of the defendant would seem to be a potential source of extreme confusion to jury members. Take, for example, a case such as $R$. v. Church $^{34}$, where both murder and manslaughter are charged. If as in Church the defence of provocation is raised, the jury will be directed, in accordance with D.P.P. v. Camplin, ${ }^{35}$ that they must take account of such of the defendant's individual and permanent characteristics which have had the effect of making the victim's remarks or conduct particularly provocative to him (the defendant). However, if provocation is not established, but instead it is found by the jury that the defendant lacks the necessary mens rea for murder, they may then be required to consider whether involuntary manslaughter is established. In directing the jury in relation to manslaughter by reckless conduct the judge will be placed in the

32. (1984) 79 C.A.R. 334.

33. See my comment, supra, at n.29.

34. [1965] 2 All E.R. 72.

35. (1978) 67 C.A.R. 1. 
invidious position of now having to inform the jury that the issue of whether the defendant was reckless must be considered without reference to any of his personal characteristics.

It is submitted that the foregoing analysis illustrates unequivocally that in the majority of cases 'recklessness' may be established merely from the actus reus, for example, of creating an obvious and serious risk of property damage. In such a case, Lord Diplock's instruction is that a jury may infer the necessary state of mind.$^{36}$ Furthermore, an examination of the directing mind will generally be superfluous, for both the first defendant who appreciates such a risk has been created, and the second defendant who does not, are equally 'reckless' in the language of Caldmell.

In contrast to what has already been stated, however, there may be a residual class of case where a true consideration of the defendant's mind is required. It is here submitted that only to this extent does the Diplock direction preserve the requirement of mens rea. It is to this exceptional class of case that attention will now be directed.

\section{The so-called 'lacuna' from Caldwell - the third mental state}

Returning once more to the direction in Lawrence, Lord Diplock stated ${ }^{37}$ that if the jury were satisfied that an obvious and serious risk had been created by the defendant, they were: ". . . entitled to infer that he was in one or other of the states of mind required to constitute the offence and will probably do so; but regard must be given to any explanation he gives as to his state of mind which may displace the inference," (author's emphasis).

As the above direction is crucial in delineating the boundaries of the new test of recklessness, its importance cannot be overstated. It is quite clear, to use Lord Diplock's terminology, that there exist only two 'mental states', and further, that having established the actus reus (obvious and serious risk of harm) the jury may generally infer that the defendant falls into 'one or other of the' two applicable states of mind. However, his Lordship then issued the imperative caveat that regard must be given to any explanation which may illustrate that the defendant is not within either of the states of mind. The inevitable corollary, therefore, is that if the defendant adduces evidence to show he does not fall within either of the mental states he cannot be termed 'reckless'.

The lacuna to Caldwell recklessness was thus born. It is urged that lacuna must not be interpreted as 'loop-hole', the latter term being suggestive of an oversight or unintended omission. it is contended, rather, that the existence of the lacuna is central to Lord Diplock's repeated assertion that 'recklessness' continues to represent a state of mind. ${ }^{38}$ The argument has been forcefully put by Professor J. C. Smith:

36. [1982] A.C. 510 , at p.527.

37. Ibid.

38. For a different view, see Birch, "The Foresight Saga: the Biggest Mistake of all" [1988] Crim L.R. 4. 
"It has been questioned whether Lord Diplock intended to leave this 'lacuna'. It is submitted that he must have done. He was insistent that recklessness was a state of mind of the defendant. Without the lacuna that view is untenable. [Otherwise] if there was an obvious and ... serious risk the defendant would then be liable whatever he thought; so there would be no need to inquire."39

Returning to Bell, it was there argued that an explanation existed within the Diplock caveat to displace the inference of recklessness. However, if those facts are recalled all the defendant was explaining was $w h y$ he failed to consider the risk of harm - the voice of God argument. This, however, in no way rebutted the inference that he was within one of Lord Diplock's 'mental states'. It simply amounted to a confirmation that he fell within the Caldwell test. The reason why he was within it, as in Elliott, was irrelevant.

Accordingly, in order that the 'explanation' be effective to prevent the defendant being adjudged reckless, its effect must have been that the defendant fell neither into the class of defendants which had failed to give thought to the risk, nor that class which had considered the risk yet gone on nevertheless to take it. With this in mind, it is lamentable that the claim mooted in Bell that "he recognised that there was a risk, but felt that he was able to cope with it because he was driven on by God", ${ }^{40}$ was apparently not pursued. It is contended that if this belief in God's intervention led the defendant actually to believe that there was no risk, or none more than negligible, the defendant's explanation has removed him from either of Lord Diplock's required mental states, and he cannot be regarded as 'reckless'. On this assumption the defendant is neither someone who has failed to recognise the risk, nor is he someone who has recognised the risk and gone on regardless. He only continued because he believed God would intervene to prevent any harm ensuing. ${ }^{41}$

When it is borne in mind that not only must the defendant subjectively hold the belief that no, or only a negligible, risk exists, but in addition he must convince the jury that this belief was actually held, it is perhaps unsurprising that this claim was not pursued in Bell. A far more likely candidate to come within the lacuna to Caldwell, it is submitted, is the defendant whose explanation, which is relied upon to show that he was not within either of Lord Diplock's 'mental states', illustrates an awareness of the risk, coupled with a certain determination and conscientiousness to avoid it.

In accordance with Lord Diplock's direction expressed above, it would seem that the defendant who has displayed reasonable assiduity in satisfying himself that

39. [1986] Crim L.R. 406, at p.408.

40. [1984] 3 All E.R. 842, at p.844.

41. A possible lacuna case is $R$. v. Crossman [1986] C.L.R. 406. Here the defendant was convicted of causing death by dangerous driving after the load on his lorry had fallen off killing a pedestrian. When he had earlier been wamed of the danger of the load toppling from the lorry, the defendant had replied that it was as "safe as houses". If he had considered the risk and decided there was none before making this reply, it is contended he could not be considered Caldwell reckless. This point was seemingly not explored since he changed his plea to guilty. 
no, or merely a negligible, risk exists before proceeding to do the act in question, falls outside both of Lord Diplock's 'states of mind' and accordingly could not be termed 'Caldwell reckless'. The limitations of the lacuna must, however, be stressed. A heavy onus rests upon the defendant to establish, to the jury's satisfaction, that he believed he had succeeded in reducing the risk to at least negligible proportions. If it is shown that any residual risk, being more than negligible, was known by the defendant to accompany his conduct, the presence of such a degree of risk brings the defendant firmly within Caldwell principles, i.e. to that extent the defendant has recognised the existence of risk and gone on nonetheless to take it.

With the aforementioned caveat in mind there is no dearth of distinguished academic opinion testifying to the existence of the lacuna. Professor Griew, in his valuable article, "Reckless Damage and Reckless Driving: living with Caldwell and Lawrence", "2 has concluded that the defendant who is aware of the risk and accordingly takes precautions (which in the event are inadequate), intending to eliminate, or reduce the risk to negligible proportions, does not fall within the Caldmell definition of recklessness. Such a person falls outside both the class of person which has given no thought to the risk and that class which has recognised the risk but proceeded nevertheless to take it. The postulant has given thought to the obvious risk, and his decision to continue the activity has only been reached after he has (mistakenly) satisfied himself that no, or only a negligible, risk remains. The lacuna is also envisaged by the authors of Smith and Hogan who observe $^{43}$ that once an obvious risk is proved, "He [the defendant] can escape only if he considered the matter and decided that there was no risk, or a 'negligible' risk."

In Griew's article (supra) a second mental state is identified which he also considers to fall outside the ambit of Caldwell recklessness. ${ }^{44}$ The example given in support of this contention is that of the defendant who considers the risk and concludes mistakenly that there is no risk, or only one which would be considered negligible. He had addressed the trivial risk but missed the obvious and substantial one.

In relation to this second of Professor Griew's scenarios it is contended, with respect, that this is a non sequitur in terms of Lord Diplock's definition. Where an obvious and serious risk of harm materialises, as a result of the defendant's conduct, awareness of an associated risk of minimal proportions is irrelevant. In the language of Lord Diplock, the defendant is someone "who has not given any thought to the possibility of there being any such risk", and is accordingly reckless. By prefacing the noun "risk" with the qualification of "such", Lord Diplock must have been referring to the obvious and serious risk which has in fact achieved fruition. 
Furthermore, if Professor Griew's contention be correct it could produce results bizarre in the extreme. Take the following example. Two defendants, acting independently, but whose conduct is identical, bring about obvious and serious risks of harm, materialising in the form of injury to P1 and P2. The risk of harm for which D1 is responsible is accompanied by a trivial risk of harm which D1 considers and dismisses. According to Professor Griew the fact that D1 has recognised the trivial risk and considered that its incidence is insufficient to affect his course of conduct, will operate to remove D1 from either of the mental states in Caldwell. Assuming that D2 failed to address his mind to the possibility of any risk of harm materialising, he will, however, be considered reckless. It is clearly undesirable that the concept of recklessness, instrumental in so many offences, should be susceptible to such a fortuitous circumstance. It is submitted that Lord Diplock's instruction, properly construed, would ensure the uniform treatment of both D1 and D2; neither had considered the possibility of the actual, obvious and serious risk materialising, and assuming the risk to be also unjustified both defendants will be adjudged reckless.

By way of amplification, the following example, inspired by the law of tort, may be useful. ${ }^{45}$ The defendant is responsible for transporting animals by sea. In accordance with legislation he is liable (inter alia) if through his recklessness any loss of life to the animals occurs. As a consequence of a decision to place the animals on the deck of the ship unpenned, an obvious and serious risk of loss of life is caused due to the danger of their being washed overboard. Is the defendant to be exempted from liability under the legislation, when all the animals are washed overboard and killed, because the risk which he had recognised and averted was the risk of the animals communicating contagious diseases to each other? He had addressed his mind to this risk and had satisfied himself that it was at most negligible because all the animals had been vaccinated. According to Griew, the answer seemingly is in the affirmative.

The former of Griew's examples however does, it is contended, present a state of mind which is not reckless in the Caldmell sense. As has been previously observed, it would appear that the conscientious defendant who, to the jury's satisfaction, genuinely believed that he had successfully eliminated the risk, or reduced it to negligible proportions, cannot be termed reckless. In the language of Lord Diplock, the explanation by the defendant as to his state of mind, comprising the evidence of his conscientiousness, displaces any inference of recklessness, for he no longer falls within "one or other of the states of mind required to constitute the offence".

The recent decision of Chief Constable of Avon ES Somerset Police v. Shimmen ${ }^{46}$ would appear however, prima facie to deny the existence of the lacuna. The facts of the case, as with Caldwell, concerned a prosecution under the Criminal Damage 
Act 1971. This had arisen when the defendant, in a state of some inebriation, ${ }^{47}$ had attempted to demonstrate to his friends his prowess in the Korean art of self-defence, but had succeeded only in demolishing a plate glass shop window. He had aimed a kick at the window intending to stop just short of making contact with the glass. Unfortunately, his belief in his faculties of control was, much like his kick, misplaced.

Shimmen is the only reported case where the defendant has contended that he falls beyond the Caldwell formulation by reason of his own belief, held at the time, that his special skills would reduce the incidence of risk. It was therefore contended that the defendant was neither someone who had given no thought to the risk; nor was he someone who had considered the risk and continued regardless. Nevertheless, it was determined by a Divisional Court that the accused was guilty of the offence charged, the ingredient of recklessness having been made out. The decision fuelled much academic disquiet amongst the subjectivists. Caldnell was viewed as having been heretically extended at a time when the academic debate had hitherto been uniform in attempting to 'contain' Caldmell by focusing upon the lacuna.

Before the Justices however the defendant had been successful in his contention that he had not acted recklessly. It was decided that his efforts to avoid any damage by aiming a controlled kick, coupled with his own belief in his skills and experience, prevented him from falling under either of the mental states described by Lord Diplock in Caldwell. As has been observed, however, on appeal to the Divisional Court it was determined that Shimmen fell firmly within the Diplock definition of recklessness. Viewed at its most general level, the decision of the Divisional Court would seem to work an unwelcome extension of Caldwell. As the defendant had clearly considered the risk of damage to the window, the only question was whether he had then proceeded nevertheless to take it. Taylor J delivered the judgment of the Divisional Court, with which Watkins LJ concurred. The learned judge referred to Professor Griew's analysis of Caldwell and Lamrence and found himself in concert with Griew's assertion that the defendant who having recognised and averted a trivial risk is not reckless when the obvious and serious risk achieves fruition. Taylor J disagreed, however, with Griew's other contention that the defendant who has considered the risk but has then taken precautions which he believes to be effective in eliminating it, is not Caldwell reckless. $\mathrm{He}$ concluded:

47. It was settled by the House of Lords in D.P.P. v. Majemski [1977] A.C. 443 that intoxication is no defence to an offence which could be committed recklessly/maliciously. This principle has survived the general separation of the two types of mens rea achieved in Caldwell: see, e.g., the dissenting judgment of Lord Edmund Davies in Caldwell. 
"He [Professor Griew's defendant] seeks to rely upon the fact that he did take precautions which were intended, and by him expected, to eliminate the risk. He was wrong, but the fact that he was conscientious to the degree of trying to minimize the risk does not mean that he falls outside the second limb of Lord Diplock's test." 48

The learned judge concluded that, "Applying those principles to the present case" the appeal should succeed, with the defendant falling within the Caldwell definition of recklessness. It would appear, therefore, that Taylor J considered the defendant before him to be indistinguishable from the hypothetical postulant of Professor Griew. However with respect, that, quite plainly, is not the case. The key to Professor Griew's exception lies in the defendant's belief that he had, by taking precautions, eliminated the risk (or at least reduced it to negligible proportions). As the passage reproduced from Shimmen above shows, Taylor J refers first to Professor Griew's postulant as having the belief that he has eliminated the risk, and in the next sentence this belief is reduced to having simply minimized the risk. This clearly shows that Taylor $\mathrm{J}$ had not been made aware of the significance attached to the distinction, and it would appear that the Judge understood Professor Griew's example to refer to a defendant who believed the risk had merely been reduced. Furthermore, the evidence in Shimmen itself, as emphasised by the Judge, was that the defendant believed his expertise in martial arts would reduce, rather than eliminate, the likelihood of the risk materialising. Having re-iterated the findings of fact of the Justices, Taylor J observed: "... [the] defendant did perceive ... that there could be a risk, but by aiming off rather more than he normally would ... he thought he had minimized it ..."49

It is important to note at this stage that in order to observe fidelity to Caldwell principles, Taylor J must have been speaking in terms of residual risk, and it was a recognition of this by Shimmen which brought him within the Diplock test. It has already been observed that the defendant who recognises that, even after account is taken of his special skills, a residual and real risk remains, will fall within the Diplock test; he is simply an individual who has recognised that some risk attends his act, but who has proceeded nevertheless to take it. Such an analysis leads to the conclusion that whilst Shimmen's own evidence, which revealed an awareness of a residual degree of risk, condemned him to being adjudged reckless, Professor Griew's postulant would still appear to be beyond the clutches of Caldwell. The logic behind such an assertion rests upon the fact that the latter's belief that the risk has been eliminated brings about the absence of any perceived residual risk, the presence of which is crucial in cases such as Shimmen, being the catalyst which activates the Diplock formula.

It is apparent from the above discussion that the ratio in Shimmen is entirely 
consistent with Lord Diplock's pronouncements in Caldwell. ${ }^{50}$ Any anxiety that the decision of the Divisional Court may mark an extension of Caldwell is due, not to the decision itself, but rather to various confused obiter statements uttered by Taylor J. If, as the learned judge contended, Professor Griew's postulant remains within the Caldwell formulation, there could be no state of mind which, accompanying the creation of an obvious and serious risk, is not reckless. This is of course totally to disregard Lord Diplock's direction that regard must be given to any explanation offered by the defendant as to his state of mind. Provided the explanation which the defendant adverts to is sufficient to exclude him from the two states of mind referred to in Caldwell, he has succeeded unequivocally in exculpating himself. It has already been contended that Professor Griew's postulant does fall within the exception because he has considered the relevant (obvious) risk and has adopted means, sufficient in his mind, to avoid it. It is thus the Diplock direction to undertake this examination of the defendant's mind, as opposed to that of a reasonable man, which makes credible his Lordship's frequent assertion that the test continues to embrace mens rea.

It is regrettable that the cruciality of the lacuna was not brought to the attention of the learned judge in Shimmen with the inevitable result that the clarity of his judgment was marred. However the obiter dicta of a Divisional Court, which are apparently in conflict with two House of Lords' authorities, should not cause undue concern, provided these utterances are recognised as being divorced from the ratio of the lower court's decision. The better view may be that the cruciality of the concept of known residual risk, lacking in Griew's first postulant above, eluded Taylor J, though to remain in harmony with Caldwell his decision depended upon it. It is contended therefore that Shimmen would only represent an extension of Caldwell if the defendant had been adjudged reckless notwithstanding his plea, accepted by the jury, that he believed all risk (being more than negligible) of damage to the window had been eliminated.

An alternative explanation for the Judge's assimilation of the defendant who is conscientious in his attempts (believed by him to be successful) to eliminate the risk, with the accused in Shimmen, is derived from the following enigmatic observation of the Judge: "Lord Diplock's second limb is simply whether or not the defendant has recognised that there was some risk." 51

On the basis of what I will call abstract risk, Taylor J may be understood as concluding that a defendant is reckless if he is aware of the risk which would, in the absence of precautions, attend his act; recklessness is here being derived from an awareness of risk in general terms. Evidence that Taylor J considered the existence of abstract risk to be important, is to be found earlier in the same paragraph of his judgment where he seems to conclude that Professor Griew's first postulant (above) was necessarily reckless because: "He was aware of the kind of 
risk which would attend his act if he did not take adequate precautions."

This observation is particularly objectionable because such an enquiry is clearly not relevant in assessing the defendant's mental state existing at the time of the relevant act. To pose the question as to what degree of risk the defendant appreciated might exist in the hands of someone who lacked his particular skills, or who failed to take the precautions which the defendant takes, is once again to ignore Lord Diplock's assertion that mens rea must be the prelude to a finding of recklessness. The crucial question to ask is whether the accused recognised, when doing the act, that despite the precautions taken some residual degree of risk remained. To repeat Lord Diplock's instruction from Lawrence: “. . . regard must be given to any explanation he gives as to his state of mind which may displace the inference [of recklessness]."

It has been contended that the ratio of Shimmen is entirely consistent with Lord Diplock's direction repeated above. Notwithstanding his obiter dicta, the judge reaches the conclusion that Shimmen was reckless because he appreciated some risk of harm existed when aiming the kick. This is borne out by Taylor J's close scrutiny of the evidence in order to determine if there was a sufficient indication of assiduity on the part of Shimmen to rebut the inference of recklessness. To this end the evidence that the accused thought that he had "... eliminated as much risk as possible by missing by two inches instead of two millimetres" was recognised by the Judge to be crucial. This led Taylor J to the conclusion that: ${ }^{52}$ "It was not a case of his considering the possibility and coming to the conclusion that there was no risk." 53

Implicit in the above is that if Shimmen had indeed come to the conclusion that there was no risk, or only a negligible one, and this was accepted by the jury, then there would have been no finding of recklessness. Acceptance of this proposition indicates that the presence of abstract risk was recognised ultimately by the judge as being irrelevant. As has been observed, to look only at the defendant's perception of risk in general terms - for example, how Shimmen would view the conduct of a non-expert attempting the same feat - would be in total disregard of Lord Diplock's caveat to heed any evidence of contextual significance.

It seems with respect that the judge's delphic reference to what I have termed abstract risk was the source of his confusion. If such obiter remarks are divorced from the ratio of the case we are left with only one further dilemma: why did the judge equate Shimmen's position with that of Professor Griew's second postulant (supra)?

The preferred solution, borne out by his judgment, ${ }^{48}$ is that the judge failed to appreciate the crucial distinction between the defendant who positively concludes that there is no risk in his circumstances, and the defendant who, like Shimmen, simply believes his abilities lengthen the odds of the risk materialising. The

\section{Ibid., at p.12.}

53. This would appear to be entirely inconsistent with the judge's earlier reasoning which is referred to in the text (supra p.39) as the 'abstract risk' condition. 
consequence of this error was the judge's assimilation of Shimmen with Professor Griew's postulant. It is untenable that the latter should be considered reckless on the basis of the principles laid down by the House of Lords. As has been stressed already, according to the judgment of Lord Diplock in both Caldwell and Lamrence, 'recklessness' still imports a state of mind as conventionally understood. Indeed Birch has argued ${ }^{54}$ that his Lordship was obliged to make this assertion in order to ensure that his definition of recklessness remained distinct from negligence which rather than being concerned with mens rea looks simply to the 'dangerousness' of the defendant's conduct. This distinction is guaranteed by the reservation to the defendant, who is alleged to have been reckless, of the right to proffer an explanation which may have the effect of removing him from either of the two mental states sufficient to indicate recklessness. The distinction between the new test of recklessness and negligence is, as has already been noted, adverted to plainly by Lord Hailsham in Lawrence, ${ }^{55}$ who directly contrasts recklessness with "mere inadvertence" or "mere carelessness". The practical consequences of this distinction are explored below in the context of involuntary manslaughter.

It must be stressed that the existence of the lacuna is unlikely to facilitate an escape from Caldmell in many cases. As has been observed, the third mental state is drawn very narrowly: the defendant must not have been aware, in doing the act, of any risk attaching to his conduct, except that which is merely negligible. What amounts to 'negligible' will depend upon all the circumstances, but it is submitted that in the vast preponderance of cases, Shimmen being one, it will in practice equate with a perception that no risk remains. This is because where, as in Shimmen, the conduct of the accused presents an unjustifiable risk of damage to the property of another, there can exist no risk which is negligible in the sense that the taking of it can be condoned. It will be observed that whilst in Shimmen it was acknowledged that the accused believed he had succeeded in substantially reducing the risk, it was not contended that the level of risk remaining was so slight as to be negligible.

Furthermore, although the issue of whether the defendant actually considered that he had eliminated all risk is necessarily a subjective question, as with any other subjective test, ${ }^{56}$ the more unreasonable the defendant's contention, the less likely the jury are to accept that it was actually held. ${ }^{57}$ To assist juries in assessing the credibility of the defendant's assertion in those rare cases where he claims to have believed all serious risk to have been entirely eliminated, Professor Williams has suggested $^{58}$ that judges should direct juries to consider whether the defendant

54. [1988] Crim. L.R. 4, at p.5.

55. [1982] A.C. 510 , at p.520.

56. E.g.., the subjective limb of the 'Ghosh test' of dishonesty within the law of theft: $R$. v. Ghosh [1982] Q.B. 1035 .

57. Cf. Bell, supra p.31 in text. It is for this reason that the implication of Birch [1988] Crim. L.R. 4, at p.5, that a defendant who unreasonably satisfies himself that no risk exists would necessarily avoid a conclusion of recklessness, cannot be supported.

58. (1988) 8 Legal Studies 1,74 , at p.77. 
would have subjected his wife/girl-friend or baby to similar treatment. If the answer is 'no' then an element of risk has necessarily been perceived. ${ }^{59}$ If such a test were to be adopted by judges it is not difficult to predict the likely response of the jury in a case such as Shimmen if such a claim were to be attempted. It is respectfully submitted that the strictness of such a test is merited in that it properly resolves any doubt in favour of the victim.

\section{The practical implications of Caldmell with particular reference to the lacuna: recklessness and involuntary manslaughter}

It is rarely that the House of Lords is visited twice in one day for the purposes of a definitive exegesis of but a single principle of law. That such occurred in the context of the definition of recklessness is testimony to the significance of the term. The reason behind the concept's importance may be shortly stated as being its virtual omnipresence throughout the criminal law, as an alternative to direct intention. Indeed both the Judiciary and the Legislature have favoured the inclusion of this element of mens rea in a wide range of offences wherever it has been thought expedient to incorporate some degree of moral turptitude into a crime. Such offences include the three offences of causing criminal damage under the Criminal Damage Act 1971; reckless driving under the Road Traffic Act 1972 and the Criminal Law Act 1977; offences of deception under the 1968 and 1978 Theft Acts; ${ }^{60}$ and the common law offence of reckless conduct manslaughter.

Before proceeding, two notable examples of offences to which the Caldwell definition does not apply should be examined. The first exception was formulated specifically by Lord Diplock himself, this being the Offences Against the Person Act 1861. This Act is primarily of importance today in regard to its provisions which relate to the infliction or causing of non-fatal bodily injury. ${ }^{61}$ The stipulated mens rea for these offences includes that of 'malice'. In formulating the definition of recklessness in Caldwell, Lord Diplock directly drew a contrast with the term 'malice' which he concluded was a term of art importing recklessness only in the sense of awareness. ${ }^{62}$

The second important exception, and one which does not owe its genesis to the Diplock definition, is the offence of rape, which in accordance with section 1, Sexual Offences (Amendment) Act 1976 may be committed recklessly. The

59. It should be noted that the Caldmell test will never be relevant where the offence relates to a non-fatal personal injury. In such circumstances the Offences Against the Person Act 1861 will apply, which adopts the (subjective) concept of maliciousness rather than recklessness, a distinction emphasised by Lord Diplock in Caldwell.

60. Which may be committed intentionally or recklessly: e.g., s.15(4), Theft Act 1968. Some commentators have asserted that due to the requirement of dishonesty, the Caldwell definition cannot apply. However, of. M.P.C. v. Charles [1977] A.C. 177.

61. Specifically, ss.47, 18 and 20.

62. [1982] A.C. 341, at p.351. For an application of the subjective test see: $W$ (a minor) v. Dolbey [1983] Crim. L.R. 681; R. v. Grimshard [1984] C.L.R. 108; R. v. Morrison [1989] C.A.R. 17; and R. v. Farrell [1989] Crim. L.R. 376. 
immunity of this offence from Caldwell recklessness was developed obliquely by Lord Lane CJ in the leading case of $R$. v. Pigg. ${ }^{63}$ The learned judge purported to apply Lord Diplock's direction, mutatis mutandis, to the offence of rape, but in the process introduced a gloss ${ }^{64}$ upon the test of recklessness by equating it with 'indifference'. This latter term had consistently been used by the courts as an alternative to mere inadvertence, ${ }^{65}$ with it requiring awareness, even if only in a constructive sense; i.e. the defendant would have subjectively appreciated the risk if he had stopped to think ( $f$. Elliott $){ }^{66}$ The tacit departure from Caldwell in Pigg became express in the subsequent decision of the Court of Appeal in $R$. v. Satnam $S$, Kewal $S^{67}$ where Bristow J, distinguishing Caldwell, ${ }^{68}$ declared $^{69}$ that in the context of rape the definition of recklessness should be arrived at: "... without regard to $R$. v. Caldwell or $R$. v. Lawrence which were concerned with recklessness in a different context and under a different statute." $" 70$

It is submitted that the latter decision was decided per incuriam with the important House of Lords decision in $R$. v. Seymour ${ }^{71}$ not being brought to the attention of the court. Whilst Lord Roskill, in delivering the judgment of the House, expressed his support for "all the reasoning" behind Lord Lane's judgment in Pigg, ${ }^{72}$ it seems clear that Lord Roskill construed it as being simply an application of Caldmell. This is unsurprising as the indifference test had been carefully marinated in the language of Caldwell before being served up for subsequent judicial consumption.

It is clear from the following passage ${ }^{73}$ of Lord Roskill's judgment that he endorsed the decision of the Court of Appeal in Pigg because of its apparent fidelity to Caldwell. There was, stated his Lordship, a "... need to prescribe a simple and single meaning of the adjective 'reckless' and the adverb 'recklessly' throughout the criminal law unless Parliament has otherwise ordained in a

\section{3. [1982] 2 All E.R. 591.}

64. As recognised by Robert Goff LJ in Elliott [1983] 1 W.L.R. 939, at p.950.

65. See, e.g., the decision of the Court of Appeal in R. v. Stone and Dobinson [1977] 1 Q.B. 354, a case concerning a charge of reckless manslaughter by neglect. A post-Caldmell illustration of subjective recklessness within a manslaughter by neglect case, is provided by $R$. v. West London Coroner [1987] 2 W.L.R. 1020, where again use was made of the 'indifference' test to achieve this result.

66. A useful example of constructive awareness is provided by the pre-Caldwell decision of $R$. v. Parker [1977] W.L.R. 600. It should be noted, by comparison, that nothing short of actual awareness will suffice where the offence requires proof of malice: $R$. v. Cunningham, supra n. 3 .

67. (1983) 78 C.A.R.149

68. On the pretext that recklessness under the Criminal Damage Act is directed at a future event, whereas recklessness as employed in the Sexual Offences (Amendment) Act 1976 is directed towards an existing fact, the state of mind of the victim: $i b i d$., at p.154.

69. (1983) 78 C.A.R. 149, at p.154.

70. Cf. the dictum of Lord Lane in R. v. Pigg [1982] 2 All E.R. 591, who had stated in relation to Caldwell/Lawrence, (at p.597): “. . We do not think, however, even had we wished to do so, that we are entitled to distinguish either of these cases ... they are decisions on the meaning of the word 'reckless' albeit in different Acts."

71. [1983] 2 A.C. 493.

72. Ibid., at p.506. Lord Diplock, it is to be noted, concurred with Lord Roskill's judgment.

73. Ibid. 
particular case. That simple and single meaning should be the ordinary meaning of those words as stated in this House in Caldwell and Lawrence." The decision of the Court of Appeal in Satnam, which was decided shortly after Seymour, in introducing a definitional dichotomy to the term reckless, does so clearly without authority, and it is submitted that the new subjective test of recklessness within the context of rape can be supported neither by principle nor reason. ${ }^{74}$

Subject to the former of the above exceptions, the generally ubiquitous nature of the "Diplock definition", as has been observed, was recognised and promoted by Lord Roskill in Seymour. It has been argued that the Caldwell test embraces a form of mens rea which at best can be termed notional. Its potential application to the offence of reckless manslaughter, exposing the accused thereby to a possible sentence of life imprisonment, and at the same time dispensing with a conventional requirement of mens rea, would accordingly mark a particularly undesirable development. However, with Lord Roskill clearly promoting an expansive interpretation of Caldmell, it is unsurprising that the decision of the House was that reckless manslaughter should yield to the 'simple and single' definition of the term. This reasoning has been subsequently applied by the Privy Council in Kong Cheuk Kwan v. $R .^{75}$ to a case involving a maritime collision resulting in death; and by the Court of Appeal in $R$. v. Goodfellow ${ }^{76}$ where death resulted from an act of arson.

\section{Does Caldwell recklessness allow for a separate category of gross negligence manslaughter?}

It is a popular contention that the expansive nature of Caldwell recklessness has rendered gross negligence, as a separate head of involuntary manslaughter, otiose. Indeed Watkins LJ in the course of delivering the judgment of the Court of Appeal in Seymour opined: “. . . we are of the view that it is no longer necessary or helpful to make reference to compensation and negligence. The Lamrence direction on recklessness is comprehensive and of general application to all offences, and should be given to juries without in any way being diluted." 77 This view was endorsed by both Lord Roskill in the House of Lords, and the Privy Council in Kong Cheuk Kwan, with the latter court aligning itself to the view that gross negligence manslaughter has been abrogated due to the Caldwell definition being applied to reckless conduct manslaughter, with a consequent broadening of its scope.

74. The genesis of the indifference test, it is submitted, is to be attributed to the growing disquiet of the judiciary with the Caldmell formula, as evidenced most recently in $R$. v. West London Coroner, supra n.65. Accordingly, the regret expressed by Lord Lane in $R$. v. Morrison, supra $\mathrm{n} .62$, that there now exist two types of recklessness, must be viewed as being unduly optimistic: see the commentary to $R$. v. Farrell [1989] Crim. L.R. 376, at p.377.

75. (1985) 82 C.A.R. 18.

76. (1986) 83 C.A.R. 23.

77. (1983) 76 C.A.R. 211, at p.216. The reference to "compensation or negligence" is clearly borrowed from the language of Lord Hewart $C J$ in the seminal authority of $R$. v. Bateman [1925] All E.R. 45. 
There is certainly no dearth of evidence to substantiate such authoritative pronouncements and this arguably leads many proponents of Diplock recklessness to be seduced into the conclusion that Caldwell has become all-consuming. Those who advocate the nadir of gross negligence manslaughter are fortified in their contention by the indisputable fact that the offence of reckless conduct manslaughter is, in many respects, wider in embrace that that of gross negligence. Testimony for this proposition is provided by a consideration of the consequences which the accused must have been reckless or grossly negligent about. Whilst Seymour is certainly equivocal on this point, it would seem clear from a consideration of Kong Cheuk Kwan and Goodfellow, that the defendant need only be reckless with regard to a risk of some physical harm ensuing from his act. Accordingly, if in such circumstances death results, reckless manslaughter may successfully be charged.

It has long been settled law that in order for a charge of gross negligence manslaughter to succeed the accused must have been grossly negligent with respect to death, or perhaps serious bodily injury. ${ }^{78}$ Furthermore, the risk envisaged in Laprence includes "an obvious and serious risk ... of doing substantial damage to property." On the facts in Seymour, where the instrument of death was an eleven ton lorry which crushed the victim between it and her motor car, any reference to the damage to the car would clearly have been superfluous and would only have served to confuse the jury. Accordingly, Lord Roskill confirmed that the first instance judge had been correct in not referring to a risk of property damage "a reference which was irrelevant in this case" (author's emphasis). ${ }^{79}$

However, the spectre still remains of there being a conviction for manslaughter where, in a relevant case, there exists an obvious risk of substantial property damage, coupled with a result of the victim unexpectedly dying. The ability to mount a charge on the grounds of reckless conduct manslaughter in such circumstances would greatly simplify the task of the prosecution. ${ }^{80}$ The major obstacle to a successful conviction based on the grounds of gross negligence manslaughter has already been noted, namely establishing the nexus between gross negligence and the result of death or really serious bodily injury. The alternative charge of unlawful act manslaughter has the independent limitation that the unlawful act must also be dangerous in the sense that, objectively assessed, it must have subjected the deceased to the risk of some bodily harm (infra) ${ }^{81}$

The risk of property damage per se, irrespective of substantiality, has never

78. The risk must go to the "life and safety of the victim": Lord Hewart CJ in R. v. Bateman, ibid. at p.48.

79. [1983] 2 A.C. 493 , at p.504: see R. v. Griffiths (1989) 88 C.A.R. 6.

80. It is to be noted, however, that in Kong Cheuk Kwan the requirement of causation was stressed; the obvious and serious risk of causing substantial property damage, having materialised, must have been the cause of the victim's death.

81. Per Edmund Davies J in R. v. Church [1965] 2 All E.R. 72, at p.76. 
previously sufficed to found a manslaughter charge. ${ }^{82}$ It would appear that a conviction on the grounds of involuntary manslaughter is now given judicial sanction in circumstances where the reasonable man would not have perceived any risk of personal injury to another. The sine qua non of the offence in such circumstances becomes simply that the ubiquitous legal talisman would have considered there to exist an 'obvious and serious risk of doing substantial damage to property'. It is a sad reflection on the English judicial process that the term 'involuntary' has come to cover a result (bodily injury) that was not merely undesired, but one which may have been considered and (wrongly) eliminated. ${ }^{83} \mathrm{It}$ is apparent that this novel route to the obtaining of a manslaughter conviction has had its foundations firmly laid in Lawrence, which House of Lords' decision has presaged a potentially large and dangerous extension to the previous law.

The recent decision of $R$. v. Sangha ${ }^{84}$ may, with a material alteration of the facts, illustrate the potential scope of this new category of manslaughter. Again, this was a case brought under the Criminal Damage Act 1971. The appellant, in a state of extreme inebriation, had set fire to a flat occupied by some neighbours. The forensic evidence indicated that the fire had most probably been started when the flat was empty. Nevertheless the appellant was charged, inter alia, with setting fire to the flat being reckless as to whether such property would be damaged and, further, being reckless as to whether the life of another would be thereby endangered. Applying Lord Diplock's judgment in Caldwell, the Court of Appeal concluded that the ordinary prudent bystander would have believed there to exist an obvious risk that life would be endangered. The appellant's conviction was accordingly affirmed.

Bearing in mind the appellant's belief that the flat was empty when he started the fire, it would be interesting to speculate what the position would have been if the flat had been occupied, with death resulting. It would seem that a charge based on gross negligence may lie, but only if the belief that the flat was empty was formed in a criminally negligent way. ${ }^{85}$ By the same token unlawful act manslaughter may also lie but again subject to an important caveat, namely in this case, that the unlawful act was one which all sober and reasonable people would inevitably recognise would subject another to at least the risk of some harm resulting. ${ }^{86}$ Conversely, however, it would appear that with the prosecution

82. Cf. R. v . Fenton (1830) 1 Lew 179 where the defendant's act of trespass was considered to be a sufficiently unlawful act to form the basis of an unlawful act manslaughter charge. This extreme approach was quickly retreated from: $R$. v. Franklin (1883) 15 Cox C.C. 163. It is particularly regrettable, therefore, that a new, and potentially far-reaching, form of constructive manslaughter has emerged a century later in the form of the 'substantial risk to property' test.

83. It is to be observed that in the absence of the sufficiency of recklessness with regard to a substantial degree of property damage, the defendant's belief that he had eliminated all risk of personal injuny by bringing him within the lacuna, would otherwise exclude him from a manslaughter charge, for he has not been reckless in this regard: see, infra, pp. 47-48 in text.

84. [1988] 2 All E.R. 385.

85. $C$. the example of the AIDS sufferer postulated, infra, p.48 in text.

86. See, supra, n.81. 
concentrating almost entirely upon the actus reus, the accused could be established as having been reckless with far greater ease. All that here has to be established is that the accused created an obvious and serious risk of substantial property damage. The burnt out shell of the flat would provide incontrovertible evidence that this was so. The mens rea required for this offence is supplied readily - the accused was clearly at least Caldwell-reckless with regard to the substantial property damages and therefore the offence is complete.

If the approach above described were adopted by the courts it would represent a large extension of the boundaries of involuntary manslaughter, with the existing limitations (of Bateman and Church) being circumvented. The accused is being convicted of manslaughter because of the substantiality of the property damage, and his recklessness in that regard is all that the prosecution must prove. It may be noted that even for a charge of common assault, recklessness with regard to injuring the victims, or at least making them fear for their personal safety, is required.

The possibility of securing a manslaughter conviction in such circumstances serves to underscore the truism that the Caldwell test, requiring proof of an obvious and serious risk of causing physical injury, or substantial property damage, cannot be transported wholesale into different offences without qualification. ${ }^{87}$ It is submitted that whilst reference to property damage is wholly appropriate in the context of the simple offence of reckless driving, a crime which in itself is not result-based, it is equally inappropriate to introduce, as the touchstone of liability for another's death, the same criteria. Whilst it has to be conceded that Lord Diplock applied the composite test to the result crime of causing death by reckless driving in Lawrence, it should be borne in mind that the maximum term of imprisonment which that offence carries, in contrast to that of manslaughter, is five years imprisonment. It may also be observed that Lord Diplock in fact prefaced his instruction in Lanrence in terms that it was to provide the jury with guidance simply on what was meant by 'driving recklessly'.

The notion that recklessness with regard to property damage can supply the mental element in any crime which focuses upon personal injury or death is once again hard to square with Lord Diplock's repeated assertion that recklessness continues to represent a state of mind. It would appear that the third mental state from Caldmell is here rendered impotent; even the defendant who considers the risk of injury to another and who then takes precautions which he considers to have eliminated the risk of physical injury, will be guilty of manslaughter if death follows, provided that an obvious and serious risk of substantial property damage accompanied his act. Take the following example. The defendant, in revenge, decides to raze the victim's house to the ground. He has no intention of causing

87. Indeed, Lord Hailsham warned of the danger of general tests: [1982] A.C. 510, at p.519. As has been noted, Lord Roskill in Seymour while acknowledging the generally ubiquitous nature of the Caldmell test, expressly excluded any consideration of substantial property damage on the facts before him: [1983] 2 A.C. 493 , at p.504. 
anybody therein injury and, accordingly, before setting the house ablaze, telephones to make sure nobody is in. The victim who had failed to answer the telephone being deaf, is killed in the blaze. The defendant will seemingly be convicted of reckless manslaughter due to his intention/recklessness in regard to the substantiality of the property damage.

Nothing has been stated thus far to cast doubt upon the assertion that gross negligence manslaughter has met its nadir, with the discussion focusing principally upon the breadth which Caldmell has injected into reckless manslaughter. It would seem however that in one sense Caldwell recklessness may be narrower than the concept of gross negligence. The cause of this is once again the lacuna or third mental state arising out of the 'Diplock' test. ${ }^{88}$ The lacuna illustrates that whilst Caldmell recklessness may include constructive mens rea, in the sense that within the test falls an "act which presents a real risk of harmful consequences which anyone acting with reasonable prudence would recognise and give heed to" (e.g. Elliott $)^{89}$ it may not, on this reasoning, be viewed as a test totally devoid of mens rea. To repeat the assertion rehearsed above, the conscientious defendant who actually believes that in his case he has successfully excluded the possibility of the risk achieving fruition, has established unequivocally a lack of mens rea. The existence of the lacuna ensures, subject to the fire-raiser example above, that even the Caldmell test cannot catch the defendant whose safeguards adopted to avoid any injury have unexpectedly failed.

The above point may be graphically illustrated by an as yet hypothetical situation. Consider the defendant who has been found to have AIDS. He continues to have intercourse with his partner without telling her of his condition. She consequently contracts the disease and dies. Those who deny the existence of the lacuna to the Diplock test would necessarily treat the defendant who simply gave no thought to the disease's proliferation in the same way as the defendant who sought medical advice and understood (wrongly) that the use of a contraceptive would protect the partner. It would necessitate a linguistic aberration before the latter defendant could be included within the definition of carelessness (Lord Diplock's definition of recklessness). It is asserted that assuming he believed that the risk of communicating the disease had been eliminated, and this is accepted by the jury, the defendant cannot, under the Diplock test, be adjudged reckless (cf. Shimmen, supra).

The ability, via proof of conscientiousness, to avoid a conclusion of recklessness, would not appear to be relevant where it is alleged that the defendant was grossly negligent however. If these twin contentions are borne out it would clearly cast doubt upon the assertions of Watkins L.J., in the Court of Appeal in Seymour, and concurred in by the Privy Council in Kong Cheuk Kman, that the new

88. Cf. Griew. [1981] Crim. L.R. 743, at p.751 where, in the context of reckless driving, it is contended that the lacuna would not apply where there would be liability for gross negligence.

89. [1982] A.C. 510 , at p.525. 
form of reckless conduct manslaughter has led indubitably to the nadir of gross negligence manslaughter.

Returning to the example postulated above of the AIDS sufferer: notwithstanding the decision of the Divisional Court in Chief Constable of Avon E Somerset Police v. Shimmen, provided the jury believe the defendant's assertion that he thought the use of a contraceptive actually eliminated the risk of communicating the disease, he cannot be reckless in the Caldwell/Lawrence sense. He is not a defendant who has given no thought to the risk which attends his act, for he has recognised the danger of the disease being transmitted sexually. Neither is he a defendant who has recognised the risk but has 'nonetheless gone on to do it'. Evidence of conscientiousness which has led to a (mistaken) belief that the risk is eliminated by the precautions adopted, shows that he has not gone on to take the risk regardless of consequence. Accordingly, when the disease is communicated to the partner, who subsequently dies, the defendant cannot, by virtue of the lacuna to the Diplock test, be convicted of reckless conduct manslaughter. This leaves the two 'established' categories of involuntary manslaughter, namely those based upon an unlawful act or gross negligence. Assuming that the victim had no knowledge of the defendant's affliction, there is the absence of any assault or battery on which to base an unlawful act manslaughter charge. ${ }^{90}$

It is contended however that the judge on these facts should properly direct the jury that what the defendant has done could be regarded in law as being grossly negligent behaviour. Notwithstanding the use of a contraceptive, the conduct of the accused, objectively assessed, would be likely to be considered by the jury to be sufficiently heinous to amount to gross negligence. The evidence would show there to have been a manifest disregard of the victim's right to self-determination and this would be likely to be enough to convince the jury that proof of the crime had been properly made out. In order for the gross manslaughter charge to be established it will also be necessary for the jury to consider the nature of the consequence to which the victim has been subjected. In the language of Lord Hewart $C J$ in $R$. v. Bateman, ${ }^{91}$ the defendant's negligence must have gone "... beyond a mere matter of compensation between subjects and [shown] such disregard to the life and safety of others, as to amount to a crime against the State ..."

The postulated case seems arguably to fall within the above dicta. The potentially fatal consequences of contracting the disease would satisfy the stricter result requirement which characterises this class of involuntary manslaughter.

The existing case-law provides another example which illustrates that there is a continuing role for gross negligence manslaughter. In $R$. v. $L a m b^{92}$ the Court of Appeal had to consider the question of whether the appellant was to be legally

90. In such a case the victim's consent to the nature of the act apparently prevents the commission of an assault or battery: $R$. v. Clarence (1888) 22 Q.B.D. 23; see also $R$. v. Lamb [1967] 2 All E.R. 1282. 91. [1925] All E.R. 45, at p.48.

92. [1967] 2 All E.R. 1282. 
responsible, in manslaughter, for the death of his best friend. The friend had been killed when the appellant pointed a loaded revolver at him in the belief that, though two of the chambers had bullets in them, the firing chamber was empty. However, unknown to the appellant, the action of pulling the trigger rotated the chambers of the gun bringing a bullet in line with the firing pin, causing the revolver to fire. The Court of Appeal quashed the appellant's conviction based on unlawful act manslaughter, holding that as both friends had been acting in jest there was an absence of any assault and therefore no unlawful act. Rather generously, perhaps, the Court of Appeal concluded that the trial judge's mis-direction to the jury on the question of the requirement of an unlawful act also tainted the latter's finding of gross negligence manslaughter and the appellant was acquitted.

If a similar case were to arise today it is submitted that the act of checking that the chamber was empty would supply the necessary diligence to prevent the defendant from being adjudged reckless. Having positively concluded that the chamber contained no bullet he has thereby considered that all risk of harm has been eliminated ( $f$. Shimmen, supra). Applying the test proposed by Professor Williams (supra), the credibility of the defendant's claim would be gauged by asking: "Would the defendant have subjected his wife/girlfriend to similar treatment?' As the two men in Lamb were best friends it would seem that the appellant would certainly have passed through the credibility threshold.

Accordingly, it would seem that if a similar case were now to arise the only available category of manslaughter with which the defendant could be charged would be gross negligence. It would be difficult to refute the assertion that the conduct of firing a gun, known to be partially loaded, with an absence of justification (e.g., self-defence), is conduct of the grossest negligence. It is suggested, therefore, that those who mourn the demise of gross negligence manslaughter have failed to appreciate the significance of the lacuna from Caldwell which ensures, at least for the time being, the continuing longevity of this category of involuntary manslaughter.

\section{Conclusion}

It is hoped that the foregoing analysis has established both the reality and importance of the lacuna. Those who regard the status of the lacuna with undue circumspection are flattering it with a scope of application which it does not merit. The twin features that the defendant must believe that the risk has been eliminated $^{33}$ and that the jury find this proposition tenable, combine to ensure that the defendant who has an unreasonable belief in his own capabilities, when pursuing an obviously risky enterprise, is likely to be adjudged reckless. Shimmen is living testimony that the actor who has an "unshakeable faith in [his] ability to

93. It has been contended that in practice there will exist no class of 'negligible' risk because any subjection of another to a risk without justifiction will be considered unreasonable:e.g., Chief Constable of Avon and Somerset Police v. Shimmen, supra n.46. 
avoid danger" $" 94$ is most unlikely to avoid a conclusion of recklessness. It is submitted that far greater danger is associated with denying efficacy to the lacuna, for here any veneer of mens rea is destroyed, and the consequent disquiet of the judges will be translated into the Caldmell formula being eroded in a piecemeal and unpredictable fashion. ${ }^{95}$

It is to be hoped that the implementation of the Law Commission's Draft Criminal Code Bill (supra) will follow without delay, restoring recklessness as an awareness-based concept. Until such statutory intervention takes place, however, there is an urgent need for certain of the judiciary to resist the temptation to indulge in the exercise of linguistic perestroika, apprised of the knowledge that so to do would be the most certain legal example of reckless behaviour. 